Jpn. J. Phys. Fitness Sports Med. 1995. $44: 513 \sim 518$

\title{
EFFECTS OF RAPID WEIGHT REDUCTION ON PROTEIN METABOLISM IN BOXING PLAYERS
}

\author{
Satoshi IwaO*, Teruaki FuziI $*$, Minako Nagai $*$, \\ KEIKO MORI $* * *$, YUZO SATO****
}

\begin{abstract}
The purpose of the present study is to investigate protein metabolism during rapid weight reduction. Six male boxing players put on a restricted diet of their own accord for two weeks. Body weight changes were observed and a biochemical analysis was made of their urine and blood. The initial body weight of $66.1 \pm 3.0 \mathrm{~kg}$ (mean $\pm \mathrm{SE})$ decreased to $63.6 \pm 3.2 \mathrm{~kg}$ after two weeks $(\mathrm{P}<0.01)$. The changes in lean body mass (LBM) by weight reduction were not significant, but the LBM tended to decrease after two weeks. The mean caloric intake was $2,791 \pm 728 \mathrm{kcal}$ before the study and 1,643 $\pm 548 \mathrm{kcal}$ after two weeks. The reduction of carbohydrate consumption is much more than that of fat and protein consumption. The $3-\mathrm{Me} / \mathrm{Cr}$ in urine increased significantly after two weeks $(348.1 \pm$ $37.0 \mu \mathrm{mol} / \mathrm{g}$ to $508.1 \pm 45.6 \mu \mathrm{mol} / \mathrm{g}, \mathrm{P}<0.01)$ and the increase of Urea-N/Cr in urine $(8.4 \pm 0.5$ $\mathrm{mg} / \mathrm{mg}$ creatinine to $13.7 \pm 1.3 \mathrm{mg} / \mathrm{mg}$ creatinine, $\mathrm{P}<0.01)$ was also significant after two weeks. Urine volume decreased significantly after two weeks $(P<0.01)$. There was no significant difference in the blood components during the weight reduction period. These results might suggest that rapid weight reduction and massive decrease of carbohydrate intake accelerate protein catabolism.
\end{abstract}

(Jpn. J. Phys. Fitness Sports Med. 1995. 44:513 518)

key words : rapid weight reduction, protein metabolism, 3-Me/Cr, and Urea- $\mathrm{N} / \mathrm{Cr}$

\section{Introduction}

Weight control is necessary to weight classification sports ; boxing, judo and wrestling. In weight reduction for these athletes, the traditional and empirical methodology is still dominant. However, analysis based on modern sciences should be introduced. The present study deals with the weight reduction, an aspect of weight control.

Athletes must reduce their weight without decreasing lean body mass (LBM) to avoid the decline of physical strength. And most athletes rely mainly on rapid weight reduction with a hard training and the reduction of food intake ${ }^{1,2)}$. In a recent study, however, it has been reported that weight reduction brings about a decrease in the isokinetic muscle strength which correlates itself with the reduction in $\mathrm{LBM}^{3)}$.

In this study, we wanted boxing players to carry out their own weight reduction by the traditional and empirical methodology. We then estimated effects of rapid weight reduction on their bodies, especially on their body protein by evaluating their protein catabolism.

\section{Materials and Methods}

A. Subjects and procedure

Six male non-obese boxers participated in this study of their own accord. Five were university boxing club members and one was an amateur
*名古屋大学大学院医学研究科健康增進科学 I

**中京女子大学

*中京短期大学

****名古屋大学総合保健体育科学センター
First Division of Health Promotion Science, Graduate School of Medicine, Nagoya University, Nagoya, Japan Faculty of Home Economics, Chukyo Women's University, Ohbu, Japan

Department of Living Science, Chukyo Junior College, Mizunami, Japan

Research Center of Health, Physical Fitness and Sports, Nagoya University, Nagoya, Japan 
Table 1. Physical characteristics of the boxing players

\begin{tabular}{ccccc}
\hline & Age (year) & Height $(\mathrm{cm})$ & Weight $(\mathrm{kg})$ & BMI \\
\hline M.T. & 22 & 175 & 66.8 & 21.8 \\
K.A. & 20 & 172 & 56.5 & 19.1 \\
K.N. & 19 & 180 & 69.4 & 21.4 \\
S.I. & 30 & 176 & 76.4 & 24.7 \\
Y.U. & 22 & 168 & 61.5 & 21.8 \\
K.U. & 20 & 174 & 66.2 & 21.9 \\
Mean \pm SE & $22 \pm 2$ & $174.2 \pm 1.8$ & $66.1 \pm 3.0$ & $21.8 \pm 0.8$ \\
\hline
\end{tabular}

boxer. They were $19 \sim 30$ years old, their mean age $22 \pm 2$, stature $174.2 \pm 1.8 \mathrm{~cm}$, and weight 66.1 $\pm 3.0 \mathrm{~kg}$. Their physical characteristics are shown in Table 1. Subject S. I., a boxer had trained for four years, fighting in major Japanese amateur championship tournaments. The others had trained for one or two years.

All subjects put on a restricted diet of their own accord for two weeks. The subjects trained themselves regularly for about 2 hours a day and 5 days a week.

Each subject's body weight was measured, and 24-hour-urine and blood samples were taken three times, before dietary restriction, after one week and after two weeks. The blood samples were collected at 9 o'clock in the morning after an overnight fast. Then, the subject's body weight and body fat rate after urination were measured by BIA method (TBF 101, Tanita, Japan). From these data, the subject's LBM was calculated. 24-hour-urine samples were collected from the second urination of the first day to the first urination of the next day, because the first urination of the first day reflects the condition of the previous day. $2 \%$ was picked up from the whole urine which the subjects urinated into their own urinal (Urine Mate, Sumitomo Bakelite, Japan). In order to avoid putrefaction, $0.02 \mathrm{ml}$ of toluene was poured into each urinal. We handed the subjects a sample of food record before the study. The kinds and quantities of foods consumed were noted for seven days before the weight reduction and then after one week and after two weeks. The subjects noted each meal, its materials and the amount of each material for each meal. Fat, protein, and carbohydrate intake and carolic intake were calculated from these data.

B. Measurements

Urinary 3-methylhistidine (3-Me) was measured by using high-performance liquid chromatography (HPLC $)^{4)}$. Urea-nitrogen (Urea-N) was measured by the Kjeldahl-Nessler method. Urinary creatinine $(\mathrm{Cr})$ was measured by the Jaffereaction method. Sensitivity of measurement was as follows : Urea-N was under $3 \%, \mathrm{Cr}$ under $3 \%$, and 3 -Me under $1 \%$.

Plasma protein was determined by the Biuret method, $A / G$ by the BCG method, uric acid by the uritase-POD method, BUN by the Urease-Uv method. Hematocrit $(\mathrm{Ht})$ and hemoglobin $(\mathrm{Hb})$ were also determined.

C. Statistical methods

Statistical analyses were made by using the Student-t test. A P-value less than 0.05 was considered significant. Mean values are given with the standard errors (SE).

\section{Results}

Training hours and menus were unchanged throughout the weight-reduction period. There- 
Table 2. Changes in caloric intake

\begin{tabular}{crcr}
\hline & before & 1 week & \multicolumn{1}{c}{ 2 weeks } \\
\hline Carbohydrate $(\mathrm{g})$ & $403.2 \pm 36.4$ & $276.3 \pm 31.9^{\star}$ & $128.7 \pm 74.0^{\star \star}$ \\
Fat $(\mathrm{g})$ & $81.3 \pm 23.2$ & $74.8 \pm 18.2$ & $50.3 \pm 17.5^{\star}$ \\
Protein (g) & $87.6 \pm 20.8$ & $73.7 \pm 11.9$ & $60.7 \pm 19.9^{\star}$ \\
All Energy Intake (kcal) & $2791.0 \pm 728$ & $2167.0 \pm 261$ & $1643.0 \pm 548^{\star \star}$ \\
\hline \multirow{2}{*}{$\mathrm{P}<0.05$} & & & (mean $\pm \mathrm{SE}$ ) \\
$\star$ **: $P<0.01$ v.s. before & &
\end{tabular}

fore, the energy consumptions a day that were calculated by watching each subject's activity changed little during the study.

A. Changes in caloric intake and weight

Mean body weight was $66.1 \pm 3.0 \mathrm{~kg}$ before the restricted diet, $65.3 \pm 3.3 \mathrm{~kg}(1.2 \%$ reduced $)$ after one week, and $63.6 \pm 3.2 \mathrm{~kg}(3.8 \%$ reduced, $\mathrm{P}<$ $0.01)$ after two weeks. The subjects achieved a mean weight loss of $2.5 \pm 0.2 \mathrm{~kg}$ after two weeks. Their mean LBM tended to decrease after two weeks, but there was no significant difference.

Table 2 shows changes in nutrition and energy. Mean caloric intake was $2,791 \pm 728 \mathrm{kcal}$ before the study, 2,167 $\pm 261 \mathrm{kcal}$ after one week $(22.4 \%$ reduced), 1,643 $\pm 548 \mathrm{kcal}$ after two weeks $(41.1 \%$ reduced, $P<0.01)$. It showed a significant difference $(P<0.01)$ in the reduction rate of caloric intake between the first week and second week. Fat was reduced from $81.3 \pm 23.2 \mathrm{~g}$ before the reduction to $50.3 \pm 17.5 \mathrm{~g}$ after two weeks $(38 \%$ reduced). Protein was reduced from $87.6 \pm 20.8 \mathrm{~g}$ before the reduction to $60.7 \pm 19.9 \mathrm{~g}$ after two weeks ( $31 \%$ reduced). Carbohydrate was reduced remarkably from $403.2 \pm 36.4 \mathrm{~g}$ before the reduction to $128.7 \pm 74.0 \mathrm{~g}$ after two weeks $(68 \%$ reduced). After two weeks, fat, protein and carbohydrate intakes were reduced significantly from those before the study $(\mathrm{P}<0.05, \mathrm{P}<0.05$, and $\mathrm{P}<$ 0.01 respectively). The method of food reduction in each subject was stable for the first week and second week, respectively.

\section{B. Changes in urine component}

The mean 3-Me and Urea-N were reduced significantly after one week and after two weeks ( $P$

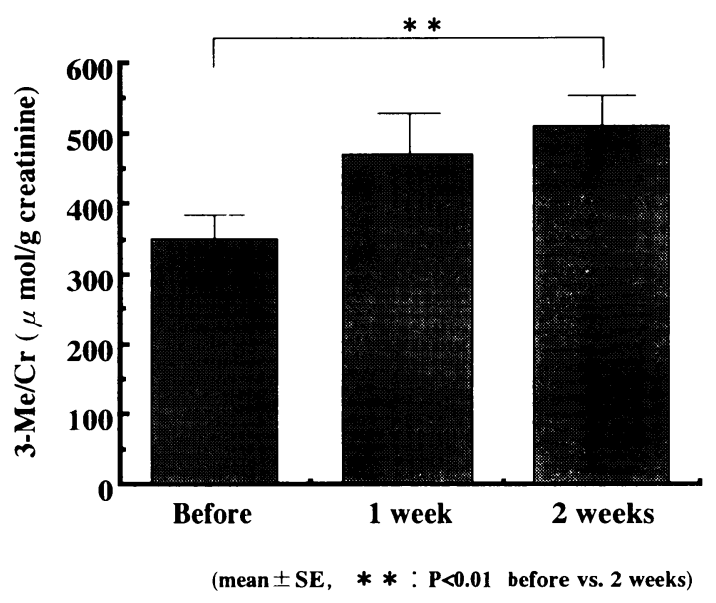

Figure 1. Changes in urinary $3-\mathrm{Me} / \mathrm{Cr}$ during weight reduction period (values are mean $\pm \mathrm{SE}$ )



Figure 2. Changes in urinary Urea-N/Cr during weight reduction period (values are mean $\pm \mathrm{SE}$ ) 


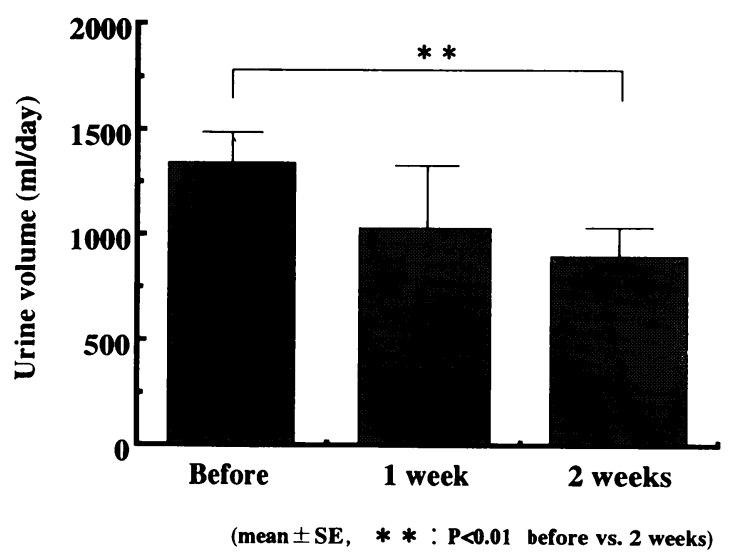

Figure 3. Changes in urine volume during weight reduction period (values are mean $\pm \mathrm{SE}$ )

Table 3. Changes in blood components

\begin{tabular}{crrr}
\hline & before & 1 week & \multicolumn{1}{c}{2 weeks } \\
\hline Protein (g/ dl) & $7.5 \pm 0.2$ & $7.6 \pm 0.2$ & $7.7 \pm 0.2$ \\
A/G & $2.1 \pm 0.1$ & $1.9 \pm 0.1$ & $2.1 \pm 0.1$ \\
Uric Acid (mg / dl) & $5.8 \pm 0.4$ & $5.5 \pm 0.2$ & $5.9 \pm 0.5$ \\
BUN (mg / dl) & $14.2 \pm 1.4$ & $14.8 \pm 2.0$ & $18.3 \pm 1.5$ \\
Ht (\%) & $42.0 \pm 1.3$ & $43.2 \pm 1.1$ & $43.2 \pm 0.5$ \\
Hb (g/ dl) & $14.3 \pm 0.5$ & $15.0 \pm 0.4$ & $14.6 \pm 0.2$ \\
\hline
\end{tabular}

$<0.01) .3-\mathrm{Me} / \mathrm{Cr}$ increased significantly after two weeks $(\mathrm{P}<0.01)$ (Figure 1). Urea-N/Cr also increased significantly after two weeks $(P<0.01)$ (Figure 2). Urine volume significantly decreased only after two weeks $(\mathrm{P}<0.01)$ (Figure 3$)$.

$\mathrm{C}$. Changes in blood components

Protein, BUN and $\mathrm{Ht}$ tended to increase, but there were no significances. There were no changes in $A / G$ and uric acid (Table 3 ).

\section{N. Discussion}

It has been reported that rapid weight reduction causes less reduction of body fat than protein catabolism ${ }^{5)}$. Protein catabolism inevitably results in a decrease in athletic ability ${ }^{6)}$. Athletes require superior ability in competition, and therefore a method of weight reduction that preserves phy. sical fitness is needed. Various combinations of low-carbohydrate and high-fat foods, lowcarbohydrate and high-protein foods or highcarbohydrate and low-fat foods, etc have been proposed as a suitable weight-loss diet. A recent study suggests, however, that extreme shortage of carbohydrates induces protein catabolism even if there is a sufficient protein supply ${ }^{7)}$.

3-Me is an analogue of histidine found predominantly in muscle actin and myosin ${ }^{8)}$. It is post-translationally found by methylation of histi. dine and cannot be reutilized for protein synthesis ${ }^{9)}$. Therefore, $3-\mathrm{Me}$ is a suitable amino acid for monitoring the degradation rate of 3 -Me-containing proteins ${ }^{10)}$.

Urea- $\mathrm{N}$ is a metabolically changed product of protein and forms $50 \%$ of residual nitrogen. It is excreted by the kidney and is used no more. It is reported that the excretion quantity of Urea- $\mathrm{N}$ is 
related with amino acid catabolism ${ }^{11)}$.

Creatinine is a normal waste product of muscle energy metabolism, formed by the nonenzymatic hydrolysis of free creatinine, which is liberated during the dephosphorylation of creatininephosphate. 24-hour urinary creatinine excretion correlates well with the total body muscle mass in each individual with normal renal function and sufficient food ${ }^{12)}$. Therefore, 3-Me/Cr and Urea$\mathrm{N} / \mathrm{Cr}$ are used to correct the error by the muscle volume and differences of renal clearance ${ }^{13)}$.

In this study, significant increases of 3$\mathrm{Me} / \mathrm{Cr}$ (Figure 1) and Urea-N/Cr (Figure 2) were observed during the weight reduction period. In addition, the LBM tended to decrease by weight reduction after two weeks (LBM : $54.7 \mathrm{~kg}$ before the reduction, and $53.3 \mathrm{~kg}$ after two weeks). From these results, we consider that the protein catabolism was caused by the rapid weight reduc. tion.

A massive decrease in carbohydrate intake was found during the study (Table 2). Judging from glucose-alanine cycle, Lemon et $\mathrm{al}^{14)}$ reported that protein and amino-acids are used as energy sources, when the quantity of carbohydrates in the body becomes insufficient. There may be some possibility, that amino-acids produced through protein catabolism in skeletal muscles are used as a main source of energy. It might be also considered that the extreme restriction of car. bohydrates, together with a shortage of protein, induces a decrease in muscle glycogen, which accelerates protein consumption for energy. As a result, protein catabolism increases.

It was once suggested that well-balanced meals totaling $1,200 \mathrm{kcal}$ a day supply sufficient quantity of necessary minerals and vitamins ${ }^{15)}$. Katch et $\mathrm{al}^{16)}$ indicated that $0.9 \mathrm{~g} / \mathrm{kg}$ of protein is sufficient for a prepubertal male and female a day, $0.8 \mathrm{~g} / \mathrm{kg}$ of protein for an adult male and female a day.

The mean energy intake became $1,640 \mathrm{kcal}$ a day after two weeks but the protein intake of 0.95 $\mathrm{g} / \mathrm{kg}$ a day was maintained. We consider that the shortage of carbohydrates had an important part in the protein catabolism because the energy intake was sufficient for minerals and vitamins, and the protein intake met the required quantity.

In weight-classified games, athletes tend to reduce their weight in order to participate in a more light class with preserved constitution and physical strength. For this purpose, it is important not only to reduce weight, but also to preserve protein including myoprotein and to stay in good shape. Therefore, it is very important that when boxers reduce their weight, the carbohydrate intake should be properly checked, a regular amount of glycogen be supplied to muscle and the protein intake of about $1 \mathrm{~g} / \mathrm{kg}$ a day be maintained, in order to avoid protein catabolism. Based on these points, it is necessary that the caloric balance should be calculated in accordance with the energy spent ${ }^{17)}$.

Further, we found the significant decrease of the urine volume after two weeks, which suggests the possibility that the subject's body water decreased. Caldwell et al $^{18)}$ have already reported that the athlete's exercise ability is lowered by dehydration. Therefore, athletes must be careful about their water intake, not to mention the nutrition during weight reduction period.

(Received, Nov. 29, 1994)

\section{Acknowledgements}

This study was supported in part by grantsin-aid from the National Dairy Promotion and Research Association of Japan.

\section{References}

1) Lakin, J. A., Steen, S. N., and Oppliger, R. A. Eating behaviors, weight loss methods, and nutrition practices among high school wrestlers. J. Community Health Nurs., (1990), 7 :223-234. 
2) Smith, N. J. Gaining and losing weight in athletics. JAMA, (1976), $236:$ 149-151.

3) Krotkiewski, M., Grimby, G., Holm, G., and Szczepanik, J. Increased muscle dynamic endurance associated with weight reduction on a very-low-calorie diet. Am. J. Clin. Nutr., (1990), 51 : 321-330.

4) Aliqureshi, G., Van Den Berg, S., Gutierrez, A., and Bergstrom, J. Determination of histidine and 3-methylhistidine in physiological fluids by highperformance liquid chromatography. J. Chromatography, (1984), $297: 83-89$.

5) Alpert. S. S. The energy density of weight loss in semistarvation. Int. J. Obes., (1988), 12 : 533-542.

6) Nieman, D. C. Vegetarian dietary practices and endurance performance. Am. J. Clin. Nutr., (1988), 48 : 754-761.

7) Dietz, W. H. Jr., and Wolfe, R. R. Interrelationships of glucose and protein metabolism in obese adoles. cents during short-term hypocaloric dietary therapy. Am. J. Clin. Nutr., (1985), $42: 380-390$.

8) Asatoor, A. M., and Armstrong, M. D. 3methylhistidine, a component of actin. Biochem. Biophys. Research Comm., (1967), 26 : 168-174.

9) Young, V. R, Alexis, S. D, Baliga, B. S, and Munro, H. $\mathrm{N}$. Metabolism of administered 3-methylhistidine: Lack of muscle transfer ribonucleic acid charging and quantitative excretion as 3-methylhistidine and its $\mathrm{N}$-acetyl derivative. J. Biol. Chem., (1972), 247 : 3592-3600.

10) Young, V. R, and Munro, H. M. N-rMethylhistidine (3-methylhistidine) and muscle protein turn over: An overview. Fed. Proc., (1978), $37: 2291-2300$.

11) Miller, A. T. Jr., and Blyth, C. S. Estimation of lean body mass and body fat from basal oxygen consumption and creatinine excretion. J. Appl. Physiol., (1952), $5:$ 73-79.

12) Dohm, G. L., Williams, R. T., Kasperek, G. J., and van Rij, A. M. Increased excretion of urea and $\mathrm{Nr}$-methylhistidine by rats and humans after a bout of exercise. J. Appl. Physiol., (1982), 52 : 27-33.

13) Dohm, G. L., Tapscott, E. B., and Kasperek, G. J. Protein degradation during endurance exercise and recovery. Med. Sci. Sports Exerc., (1987), 19 : S 166-S 171.

14) Lemon, P. W. R., and Mullin, J. P. Effect of initial muscle glycogen levels on protein catabolism during exercise. J. Appl. Physiol., (1980), 48 : 624-629.

15) McDonald, R., and Keen, C. L. Iron, zinc and magnesium nutrition and athletic performance. Sports. Med., (1988), 5 : 171-184.

16) Katch, F. I., and McArdle, W. D. Nutrition, Weight, Control and Exercise. $3 \mathrm{rd}$ Ed., Lea \& Febiger, Philadelphia, (1988).

17) Morita, Y., Igawa, S., Takahashi, H., Tomida, K., and Hirota, K. Effects of rapid weight reduction diet on protein metabolism and physical performance. Ann. Physiol. Anthropol., (1991), 10 : 25-33.

18) Caldwell, J. E. Diuretic therapy and exercise performance. Sports Med., (1987), 4 : 290-304. 